UDC 2-6(4)"19/20"

DOI 10.24919/2519-058X.20.240034

\title{
Andrzej KRYŃSKI
}

Ph.D., Professor, Rector of Polonia University in Czestochowa, 4/6 Gen. Kazimierza Pulaskiego str., Czestochowa, Poland, postal code42-226(a.krynski@ap.edu.pl)

ORCID: 0000-0001-9635-023X

\section{Valentyna BODAK}

PhD hab. (Philosophy), Professor, Professor of the Philosophy Department named after Valeriy Skotnyi, Drohobych Ivan Franko State Pedagogical University, Ivan Franko str., 24, Drohobych, Ukraine, postal code82100 (bodakvalentyna@gmail.com)

ORCID: https:// orcid.org/0000-0003-0208-5282

\section{Oleksandr TKACHENKO}

PhD (Philosophy), As-sociate professor of the Philosophy Department named after Valeriy Skot-nyi, Drohobych Ivan Franko State Pedagogical University, 24, Ivan Franko Str., Drohobych, Ukraine, postal code82100(tkacenkoaleksandr1928@gmail.com)

ORCID:https://orcid.org/0000-0002-0674-0144

\section{Анджей КРИНЬСЬКІ}

доктор суспільних наук, доктор теології, професор, Ректор Полонійної Академії в Ченстохові, вул. Генерала Казимира Пуласького, 4/6, м. Ченстохова, Польща, індекс42-226 (a.krynski@ap.edu.pl)

\section{Валентина БОДАК}

доктор філософських наук, професор, професор кафедри філософії імені професора Валерія Григоровича Скотного, Дрогобицький державний педагогічний університет імені Івана Франка, вул. Івана Франка, 24, Дрогобич, Україна, індекс 82100 (bodakvalentyna@gmail.com)

\section{Олександр ТКАЧЕНКО}

кандидат філософських наук, дочент, дочент кафедри філософії імені професора Валерія Григоровича Скотного, Дрогобицький державний педагогічний університет імені Івана Франка, вул. Івана Франка, 24, Дрогобич, Україна, індекс 82100 (tkacenkoaleksandr1928@gmail.com)

Bibliographic Description of the Article: Kryński, A., Bodak, V. \& Tkachenko, A. (2021). Religious processes in Western Europe at the end of the XXth - the beginning of the XXIst centuries. Skhidnoievropeiskyi Istorychnyi Visnyk [East European Historical Bulletin], 20, 195-206. doi: 10.24919/2519-058X.20.240034

\section{RELIGIOUS PROCESSES IN WESTERN EUROPE AT THE END OF THE XXth - THE BEGINNING OF THE XXIst CENTURIES}

Abstract. The purpose of the article is a conceptual identification of religiosity tendencies in Western Europe at the end of the XXth - the beginning of the XXIst centuries. The methodological 
bases of the study were socio-philosophical analysis of the religiosity phenomenon, as well as historical systemic and analytical synthetic methods. The Scientific Novelty. In Western Europe new religious processes go beyond the classical contours of modernity. The dynamics of change in the field of religion takes place under conditions of uncertainty, nonlinearity, ephemerality of social processes, as well as the continuing aggravation of relations between secular culture and religion. It is necessary to be critically aware of the fact that the institutional and socio-cultural return of religion (post-secularity) causes vulgarization, the creation of various distorted forms of religiosity. Our point of view is that the decline of a traditional religiosity continues in Western Europe, which is not a localized tendency and a civilizational integration project, a transnational paradigm are being actively promoted. The Conclusions. Western societies remain a relatively secular part of the global world and differ in the level of a religious diversity and the dynamics of a religious change among their population. From the point of view of the confessional identification, Western European countries can be attributed to one Christian culture (unfortunately, practically lost). According to the criterion of religiosity level, "high religion" is characteristic of countries with the maximum number of Orthodox and Catholics. In Western Europe, there is a situation where religion is often engaged with "vicariously". In Western Europe, an important tendency in religiosity is the subjectivation of faith and practice, which complicates the preservation and transmission of religious traditions. As a result, religiosity is of a situational character.

Key words: faith, Western Europe, post-secularity, religion, religiosity, religious tradition, secularization.

\title{
РЕЛІГІЙНІ ПРОЦЕСИ В КРАЇНАХ ЗАХІДНОЇ ЄВРОПИ НА РУБЕЖІ XX - XXI ст.
}

\begin{abstract}
Анотація. Метою статті є концептуальне виявлення тенденцій релігійності в краӥнах Західної Європи на рубежі XX - XXI cm. Методологічними засадами дослідження стали соиіально-філософський аналіз феномену релігійності, а також, історико-системний і аналітикосинтетичний методи. Наукова новизна. Нові релігійні прочеси в Західній Європі, виходять за межі класичних контурів сучасності. Динаміка змін у сфері релігії відбувається в умовах невизначеності, нелінійності, швидкоплинності соиіальних процесів, а також характеризується продовженням загострення відносин між секулярною культурою і релігією. Необхідно критично усвідомлювати, що за інституиійним і соиіокультурним поверненням релігії (постсекулярність) відбувається вульгаризація, створення різноманітних спотворених форм релігійності. Ми вважаємо, щзо в Західній Європі продовжується занепад традииійної релігійності, який не є локалізованою тенденцією $і$ активно пропагується иивілізаиійний інтеграційний проєкт і транснаціональна парадигма. Висновки. Західні суспільства залишаються відносно світською частиною глобального світу та розрізняються за рівнем релігійного розмаїття $i$ динамікою релігійних змін серед їх населення. 3 точки зору конфесійної ідентифікаиії країни Західної Європи можна віднести до єдиної християнської культури (на жаль, практично втраченої). За критерієм рівня релігійності “високе віросповідання" характерне для країн з максимальною кількістю православних і католиків. У Західній Свропі склалася ситуачія, коли religion is often engaged with "vicariously". Важливою тендениією релігійності в краӥнах Західної Європи є суб' єктивація віри і практики, яка ускладнює збереження та передачу релігійних традииій. Як наслідок, релігійність має ситуативний характер.

Ключові слова: віра, Західна Європа, постсекулярність, релігія, релігійність, релігійна традичія, секуляризація.
\end{abstract}

The Problem Statement. According to many researchers, one of the main topics of our time is the problems associated with the real state of religiosity, the emergence of its new varieties, the attempts to correlate the level of civilization and a cultural development and the degree of society religiosity. These issues are caused by the place and role of a religious factor in social processes and international political events: the spread of the post-secular paradigm, the impact of a global migration on the religiosity change in European space, the search of ways of a cultural dialogue between Western society and representatives of 
other cultures, extremism and terrorism, the transformation of modern practices of traditional religious institutions, the formation and spread of new religious organizations and the others. Thus, the problems of post-secularization, religious galvanization, neo-fundamentalism, traditionalism and pseudo-traditionalism are the hallmarks of a modern spiritual life around the world, primarily the West, the most desacralized in comparison with its postcolonial periphery. However, sometimes the analysis of these phenomena, in which a well-established descriptive scale is used in academic religious studies, remains unsuccessful. This kind of analysis only records these phenomena (Tovbin, 2013, p. 86).

In the article the actualization of the problematic issue is caused by the European development vector of Ukraine. Undoubtedly, these and other tendencies are reflected complex and nonlinear - in Ukraine as well. Moreover, the problematic issue is extremely specific and worthy of the most in-depth and comprehensive research. In Europe and Ukraine harsh debates revolve around the values and identities based on religious beliefs and feelings.

Also, the study of religiosity, "Christian biography" of a historical figure through the external manifestations of "soul work", according to a historian, Professor Dmytro Volodykhin (2020), can and must become the goal of a historian's professional activity. The method of "personal history" is meant - a direction that is becoming one of the most promising in historical science at the end of the XXth - the beginning of the XXIst centuries.

In fact, the true object of analysis for personal history is the abyss of a human soul, the soul that struggles with temptation, the sinful soul that seeks to overcome sinfulness, the soul that is under pressure by external circumstances, the soul that ascends to God (Volodihin, 2020).

The Analysis of Sources and Recent Researches. The actualization of the need for an integrated approach in the study of religiosity in the article by O. Breskaja "The Study of Religiosity: the Need for an Integrated Approach" was important for our research (2011). According to the author, this is due to the history of the religiosity conceptualization in the XXth century and a special dual nature of this phenomenon - individual and group, aimed at understanding the transcendent (Breskaja, 2011).

Grace Davie emphasizes the need for new conceptual tools to understand the modern world and the place of religion in it better:

The conceptual tools that emerge from the European case may not be appropriate elsewhere. Instead we need to search for new approaches and new understandings in order to understand the nature of religion in the modern world fully - both within and outside Europe (Davie, 2004, p. 83).

In the article "Religion in Europe in the 21st Century: The Factors to Take into Account" (2006) Grace Davie also focuses on six factors that shape a religious life of modern Europe. "These are, - the British researcher writes - the Judaeo-Christian heritage, the continuing influence of the historic churches, the changing patterns of church-going, new arrivals from outside, secular reactions and the growing significance of religion in the modern world order" (Davie, 2006, p. 271). The author is convinced, that "any assessment of the future of religion in Europe must take all of these into account, not least their mutual and necessarily complex interactions" (Davie, 2006, p. 271). Noteworthy is Grace Davie's conception of "vicarious religion", which was elaborated to understand the nature of European religion. I. Kargina (2012) focuses on modern researches in the field of civic religion and civic religiosity, which are close to Grace Davie's conception of "vicarious religion". In this context, it is necessary to mention the concept "believing without belonging", which is used in Western sociology in the analysis of religiosity nowadays actively. 
The new situation of modernity - post-secularity, which became a tendency in modern Western societies - one of the main problems of a scientific research of Jurgen Habermasa. In his opinion, "Post-secular society" can really be applied to public consciousness in Europe nowadays in the sense that this society at this time does not deny the fact of the continued existence of religious communities in a secularized environment and adapts to it" (Habermas, 2008, p. 2).

But in Western sociological thought there are supporters of the theory of secularization, who emphasize that "the decline in power, popularity, and prestige of religion across the modern world is not a short-term or localized trend nor is it an accident" (Bruce, 2011). Steve Bruce's main idea consists in the fact that the social significance of religion in Europe is diminishing and this ultimately means a complete decline of faith. Gert Pickel, reflecting on the question: Secularization as a European Fate?, writes:

"...Establishing a "contextualized secularization theory" as a frame of reference for empirical analyses has a lot to commend it. We can only advance the empirical interpretation of religious developments if we combine path dependencies with additional general sociocultural explanatory models. This implies that we need to incorporate the general conditions of religion broadly ... Insisting on alternative standpoints and rejecting the secularization theory prematurely seems to obscure the perception of reality instead" (Pickel, 2006, pp. 118-119).

José Pereira Coutinho focuses on the analysis of religiosity in European countries in the study "Religiosity in Europe: an Index, Factors, and Clusters of Religiosity" (2016), in which the Portuguese researcher pays attention to the interest of modern researchers in the problem of religion and religiosity in Europe. "Modern Europe's varied cultural and religious landscape has given rise to numerous sociological studies, which either focus on one or few countries, its Eastern part, its Western part or Europe as a whole" (Coutinho, 2016, p. 164).

Victor Yelensky's scientific works are devoted to the tendencies of a religious life, their analysis and forecasts at the turn of the new millennium. In particular, in the lecture "Global Tendencies in Religious Development at the Beginning of the XXIst century" (2009) at the Ukrainian Catholic University, a well-known Ukrainian theologian emphasized the relationship between globalization and religion, the complex and ambiguous situation of religiosity in Western Europe. It is important for us to actualize V. Yelensky's idea that the tendencies of changes in a religious life should not be reduced only to a renewal. "After all, the future of religion will always depend on its ability to be both traditional and forward-looking, to value and respect its heritage, but also to be able to transcend it" (Yelenskyi, 2009).

The following data were used in writing this article: European Values Surveys (EVS), The European Social Survey (ESS), World Christian Database, Center for Religion, Economy and Politics (ZRWP); materials Pew Research Center's Forum on Religion \& Public Life, German company of the Statista, Deutsche Welle (DW), Bertelsmann Foundation, Swiss Metadatabase of Religious Affiliation in Europe (SMRE).

The purpose of the article - to identify the religiosity tendencies in Western Europe at the end of XXth - the beginning of the XXIst centuries. Such analysis can confirm or refute superficial generalizing stereotypes about a religious life in Western Europe, understand in this context the specifics of religiosity in Ukraine, understand the real challenges of today and the answers to them.

The complexity of the religiosity study is associated, primarily, with methodological problems. Also, it is very difficult for people to express their religious beliefs and feelings verbally. Thus, we can think more about external religiosity, and the internal - the invisible connection that unites a human being with God - will always remain Kant's "thing in itself". 
And even confirmation / non-confirmation of religiosity by knowledge and reading of prayers, Holy Scriptures, visits to religious buildings, observance of other cultic practices may not indicate a true religiosity (Fylypovych, 2015). After all, according to I. Ilyin, between faith and unfaith, between religiosity and without religiosity, there are many peculiar intermediate states when a person remains insecure, indecisive and unstable... Sometimes, under the crust of a theoretical disbelief, true and deep religiosity lives secretly; and vice versa, often, a pronounced church piety hides a completely non-spiritual soul... (Ilyin, 2014).

The Main Material Statement. Although confessional identification is a weak indicator of an individual's religiosity, in our opinion, it should be taken into account when analyzing the relationship between people and religion and the church, because confessionalism helps understand the historical and traditional dimensions of religiosity. At the end of the XXth - the beginning of the XXIst centuries Western European countries, from the point of view of confessional identification in general, can be attributed to one Christian culture (unfortunately, much lost), with similar political processes and structures, because $46 \%$ of people call themselves Catholics and 22\% - Protestants (other religions make up about 7\%). In Table 1 the list of countries is illustrated. Approximately the same results were obtained by European Values Surveys waves 4, 5. Although regional and global conflicts (1991 and 2001, the events of the Arab Spring, which began in 2011, mass migration to Europe in 2015, etc.) led to a reassessment of the opportunities and constraints of existing European social institutions and a real challenge for states, which for centuries remained the embodiment of Christian civilization. Pew Research Center survey of religious beliefs and practices in Western Europe', illustrated that "both church-attending and non-practicing Christians are more likely than religiously unaffiliated adults in Western Europe to voice anti-immigrant and anti-minority views" (Being Christian in Western Europe, 2018).

According to Shmuel N. Eisenstadt (2000), the new religious processes that are taking shape in Europe go beyond the classical contours of modernity and thus, "The central new development regarding the place of religion is thus that religious identity, which was in the classical model of the nation-state delegated or confined to private or secondary spheres, has become transposed into the public political and cultural arenas, thereby becoming a central, autonomous component in the constitution of collective identities" (Eisenstadt, 2000).

In fact, Europe is very diverse to be analyzed as a whole. "Western societies vary in the extent of their religious diversity and the rate of religious change among their populations" (Collins-Mayo, 2012, p. 81). In general, in Western Europe, Christians are more likely to show a high level of a national than religious pride.

Table $\mathbf{1}^{2}$. What denomination you belong to?

\begin{tabular}{|c|c|c|c|c|c|}
\hline Country & Roman Catholic & Protestant & Evangelists & Orthodox & Other \\
\hline France & 91.8 & 2.4 & 0.8 & 1.9 & 3.1 \\
\hline Great Britain & 15.4 & 60.3 & 1.7 & 0.1 & 22.5 \\
\hline Germany & 41.8 & 50.6 & 2.6 & 0.5 & 4.5 \\
\hline Austria & 91.5 & & 6.4 & 1.0 & 1.2 \\
\hline Netherlands & 51.3 & 21.0 & 16.9 & & 10.8 \\
\hline Ireland & 95.9 & 1.6 & 0.7 & & 1.9 \\
\hline Belgium & 86.3 & 1.7 & 3.1 & 0.6 & 8.3 \\
\hline
\end{tabular}

${ }^{1}$ Pew Research Center conducted surveys among 24,599 adults (ages 18 and older) across 15 countries in Western Europe. Interviewing was carried out under the direction of GfK Belgium by telephone (both cellphones and landlines) from April to August 2017.

${ }^{2}$ EVS3, 2001, p. 75 
The percentage of belonging to a religious denomination is represented in Table 2. As it can be seen in Ireland (90.7\%) and Austria (88.1\%) the majority shows the belonging to a religious denomination, but in the Netherlands - only $46 \%$.

Table $2^{3}$. Do you belong to a religious denomination?

\begin{tabular}{|c|c|c|}
\hline Country & Yes & No \\
\hline Ireland & 90.7 & 9.3 \\
\hline Austria & 88.1 & 11.9 \\
\hline Germany & 76.6 & 23.4 \\
\hline Luxembourg & 72.2 & 27.8 \\
\hline Belgium & 64.2 & 35.8 \\
\hline France & 57.5 & 42.5 \\
\hline Netherlands & 46.0 & 54.0 \\
\hline
\end{tabular}

Respondents' answers to questions about belonging to religious denomination and religiosity are closely related. The results of researches illustrate that people who say they belong to a particular denomination at the same time claim to be non-religious, while people who do not belong to a religious denomination claim to be religious. Pierre Bréchon (2008) considers that this may be a sign of distance between interpersonal attitudes and registered social affiliation, as well as a diminution of the importance of religious institutions that lost some of their power to determine the country's religious panorama.

According to José Pereira Coutinho (2016), the countries with "higher belief" are Muslim, Orthodox and Catholic (Table 3). As it can be seen, the countries of Western Europe out of 47 countries, with the exception of Ireland, are presented at the bottom of the Table with a lower index of religiosity.

Table $3^{4}$. Indicators and Dimension of Beliefs

\begin{tabular}{|c|c|c|c|c|c|c|c|}
\hline & Country & Personal God & Life after death & Hell & Heaven & Sin & Dimension $^{1}$ \\
\hline 1 & Turkey & 90.6 & 92.5 & 96.7 & 96.7 & 97.8 & 1.28 \\
\hline 6 & Georgia & 94.3 & 44.8 & 65.3 & 70.3 & 85.0 & 0.68 \\
\hline 7 & Poland & 78.5 & 66.1 & 60.8 & 70.7 & 80.9 & 0.67 \\
\hline 12 & Ireland & 53.4 & 59.7 & 42.1 & 67.2 & 67.8 & 0.32 \\
\hline 17 & Ukraine & 55.0 & 38.0 & 39.5 & 44.0 & 76.5 & 0.13 \\
\hline 24 & Great Britain & 25.0 & 44.3 & 28.6 & 46.4 & 28.6 & 0.14 \\
\hline 27 & Austria & 25.7 & 51.6 & 23.8 & 35.9 & 51.6 & -0.21 \\
\hline 31 & Switzerland & 26.4 & 44.6 & 18.3 & 39.3 & 45.6 & -0.28 \\
\hline 35 & Netherlands & 23.9 & 45.8 & 15.0 & 37.2 & 36.3 & -0.36 \\
\hline 36 & Belgium & 21.6 & 40.4 & 17.1 & 34.0 & 43.9 & -0.37 \\
\hline 40 & Luxembourg & 27.4 & 40.9 & 17.7 & 25.6 & 36.9 & -0.42 \\
\hline 41 & Germany & 21.7 & 34.7 & 16.6 & 30.8 & 42.6 & -0.43 \\
\hline 42 & France & 17.6 & 39.3 & 16.6 & 31.6 & 38.9 & -0.44 \\
\hline 47 & Sweden & 13.7 & 33.9 & 7.6 & 19.0 & 13.3 & -0.73 \\
\hline
\end{tabular}

\footnotetext{
${ }^{3}$ EVS3, 2001, p. 74

${ }^{4}$ Coutinho, 2016, p. 175.
} 
If you analyze these indices thoroughly and refer specifically to the block on attendance frequency at religious services (Table $4^{5}$ ), you can see a high percentage of those who do not attend the service in France (60.4\%), Great Britain ${ }^{6}$ (55.8), Belgium and the Netherlands. Although at the age of 12 attending religious services was much higher in France, Great Britain, Belgium and the Netherlands. Also, answering the questions about the frequency of prayers except for the prayers at religious services, which the majority of Western Europeans (except for some countries) never attend, only in Ireland (69\%) and Austria (43.3\%) the majority prays once a week (Table 5).

Table $4^{7}$. Apart from weddings, funerals and christenings, about how often do you attend religious services these days?

\begin{tabular}{|c|c|c|c|c|c|c|}
\hline Country & $\begin{array}{l}\text { Apart from } \\
\text { weddings, } \\
\text { funerals and } \\
\text { christenings, } \\
\text { about how } \\
\text { often do you } \\
\text { attend religious } \\
\text { services these } \\
\text { days? }\end{array}$ & & & $\begin{array}{l}\text { Apart from } \\
\text { weddings, } \\
\text { funerals and } \\
\text { christenings, } \\
\text { about how often } \\
\text { did you attend } \\
\text { religious services } \\
\text { when you were } \\
12 \text { years old? }\end{array}$ & & \\
\hline & $\begin{array}{l}\text { More than once } \\
\text { a month }\end{array}$ & $\begin{array}{c}\text { Special } \\
\text { occasions }\end{array}$ & Never & $\begin{array}{l}\text { More than once a } \\
\text { month }\end{array}$ & $\begin{array}{c}\text { Special } \\
\text { occasions }\end{array}$ & Never \\
\hline France & 11.9 & 27.8 & 60.4 & 63.4 & 12.2 & 24.4 \\
\hline Great Britain & 18.9 & 25.3 & 55.8 & 58.7 & 13.4 & 27.9 \\
\hline Germany & 30.1 & 41.2 & 28.8 & 54.8 & 26.4 & 18.9 \\
\hline Austria & 42.5 & 40.5 & 17.0 & 79.6 & 15.9 & 4.5 \\
\hline Malta & 87.2 & 8.9 & 3.9 & 98.0 & 1.4 & 0.6 \\
\hline Belgium & 28.0 & 25.3 & 46.6 & 77.6 & 9.0 & 13.5 \\
\hline Netherlands & 25.7 & 28.1 & 46.1 & 60.9 & 14.7 & 24.4 \\
\hline Luxembourg & 31.8 & 35.5 & 32.7 & 84.0 & 6.4 & 9.6 \\
\hline Ireland & 67.4 & 28.834 & 9.7 & 97.5 & 1.6 & 0.9 \\
\hline Northern Ireland & 63.4 & 16.9 & 19.8 & 92.0 & 2.7 & 5.3 \\
\hline Poland & 78.2 & 16.6 & 5.2 & 97.3 & 1.6 & 1.1 \\
\hline Ukraine & 16.9 & 52.7 & 30.5 & 8.1 & 34.7 & 57.3 \\
\hline
\end{tabular}

Table $5^{8}$. How often do you pray to God outside of religious services?

\begin{tabular}{|c|c|c|c|c|}
\hline Country & At least once a week & At least once a month & Less often & Never \\
\hline France & 19.6 & 5.8 & 19.6 & 55.0 \\
\hline Great Britain & 28.8 & 4.7 & 18.1 & 48.4 \\
\hline Germany & 35.8 & 8.0 & 19.7 & 36.5 \\
\hline Austria & 43.6 & 9.5 & 26.7 & 20.2 \\
\hline Italy & 62.1 & 5.8 & 19.2 & 12.9 \\
\hline Malta & 87.2 & 2.0 & 8.0 & 2.8 \\
\hline
\end{tabular}

\footnotetext{
${ }^{5}$ For comparison, as in the previous tables, we indicated some other European countries and Ukraine also.

${ }^{6}$ Church attendance in England decreased by approximately 211,000 since 2009, with the average weekly attendance of the Anglican Church in 2018 being just 870.9 thousand of people.

${ }^{7}$ We combined two tables taking the data from EVS3, 2001, pp. 78-79.

${ }^{8}$ EVS3, 2001, p. 98
} 


\begin{tabular}{|c|c|c|c|c|}
\hline Country & At least once a week & At least once a month & Less often & Never \\
\hline Belgium & 35.6 & 5.8 & 19.3 & 39.3 \\
\hline Netherlands & 33.9 & 4.5 & 13.6 & 48.0 \\
\hline Luxembourg & 32.3 & 7.3 & 26.6 & 33.8 \\
\hline Ireland & 69.0 & 8.3 & 13.5 & 9.3 \\
\hline Poland & 78.0 & 7.0 & 10.5 & 4.4 \\
\hline Ukraine & 41.4 & 8.7 & 11.2 & 38.7 \\
\hline
\end{tabular}

According to new studies of religious beliefs and customs in Western Europe, conducted by Pew Research Center, it is really so, "that non-practicing Christians (defined, for the purposes of this report, as people who identify as Christians, but attend church services no more than a few times per year) make up the biggest share of the population across the region" (Being Christian in Western Europe, 2018).

According to many researchers, young people in Western Europe are much less religious than adults. For example, Sylvia Collins-Mayo (2012), during deep interviews with young people in England, revealed their friendly (though indifferent) attitude to religion, and the very Christian life - uncertain and superficial. Thus, faith in God is a situational phenomenon. "If religion does not matter very much, what does matter to young people is being happy in life and having good and satisfying relationships with family and friends" (Collins-Mayo, 2012, p. 88). Although religion is peripheral to many young people, they remain potentially open to the possibility of faith. This is due to the fact that a religious tradition is one way or another "held within the family and the wider cultural memory (which is largely Christian)" (Collins-Mayo, 2012, p. 88). Indeed, it is the spiritual foundations of tradition, in our view, that determine its effectiveness, ontological personal and social levels. "Owing to a religious tradition, in society there are conditions not just for a human development, but the elevation of our lives to a higher level - the level of a spiritual existence" (Tkachenko, 2020, p. 114).

Actualizing the tendency of subjectivization of a religious faith and practice, S. CollinsMayo (2012) notes that it complicates the transmission of religious traditions from one generation to another. A categorical (sometimes pathological) personalistic position of Western European culture is meant, which presupposes the dominance of a personal choice in a sociopolitical and spiritual life and does not want to realize that freedom is practiced in the space of tradition. "The fact that only a minority of young people in most Western countries go to church does not bode well for the long term future of Christianity" (Collins-Mayo, 2012, p. 90).

In general, in Western Europe there is a situation when religion is often engaged with "vicariously". In other words, "the minority keep religious traditions going, and the majority (implicitly at least) are happy that they do so, for occasionally they take advantage by selectively drawing upon those religious ideas, traditions and services and when they need or want to" (Collins-Mayo, 2012, p. 91). According to a new study of religious beliefs in Western Europe, an average of $53 \%$ of respondents consider themselves neither religious nor spiritual (Being Christian in Western Europe, 2018).

David Voas (2005), reflecting on a common concept in Western scientific thought "believing without belonging", which reflects one of the laws of a religious life in Western Europe, draws the following conclusion: "Our point is simply that the crucial fact about religion in modern Europe is decline; the rest is commentary" (Voas, 2005, p. 11).

Thus, despite the fact that researchers claim a new paradigm of modernity - postsecularity, we share the point of view David Voas: "belief has in fact eroded in Britain at the same rate as 
two key aspects of belonging: religious affiliation and attendance. Levels of belief are lower than those of nominal belonging" (Voas, 2005, p. 25).

Results of answers to question from VS3 (2001): "Generally speaking, do you think that your church is/the churches are giving, in your country, adequate answers to the moral problems and needs of the individual?" (Table 6), illustrated the following percentage: in France, Great Britain, Austria, Belgium, the Netherlands the amount of people with predominantly negative attitudes towards religious organizations (respectively 64.3\%, 67.4\%, 62.5\%, 63.7\%, $65.2 \%$ ) is bigger, than the amount of people with predominantly positive attitudes towards religious organizations (respectively $35.7 \%, 32.6 \%, 37.5 \%, 36.3 \%, 34.8 \%$ ). In Germany this percentage is approximately the same (positive $-48.3 \%$, negative $-51.7 \%$ ). The majority of respondents answered the following question negatively: "Generally speaking, do you think that your church is/the churches are giving, in your country, adequate answers to problems of family life?", the data from EVS3 (2001), (Table 6).

Table $6^{9}$. Generally speaking, do you think that your church is/the churches are giving, in your country, adequate answers to...

\begin{tabular}{|c|c|c|c|c|c|c|}
\hline Country & $\begin{array}{c}\text { The moral problems and } \\
\text { needs of the individual }\end{array}$ & & $\begin{array}{c}\text { Problems of } \\
\text { family life }\end{array}$ & $\begin{array}{c}\text { People's } \\
\text { spiritual needs }\end{array}$ & \\
\hline France & Yes & No & Yes & No & Yes & No \\
\hline Great Britain & 35.7 & 64.3 & 27.8 & 72.2 & 55.4 & 44.6 \\
\hline Germany & 32.6 & 67.4 & 30.0 & 70.0 & 58.1 & 41.9 \\
\hline Austria & 48.3 & 51.7 & 39.0 & 61 & 55.5 & 44.5 \\
\hline Italy & 37.5 & 62.5 & 29.0 & 71 & 60.3 & 39.7 \\
\hline Malta & 61.8 & 38.2 & 47.7 & 52.3 & 72.4 & 27.6 \\
\hline Belgium & 66.6 & 33.4 & 75.0 & 25.0 & 85.5 & 14.5 \\
\hline Netherlands & 36.3 & 63.7 & 32.8 & 67.2 & 53.8 & 46.2 \\
\hline Luxembourg & 34.8 & 65.2 & 30.1 & 69.9 & 47.4 & 52.6 \\
\hline Ireland & 33.2 & 66.8 & 24.2 & 75.8 & 45.7 & 54.3 \\
\hline Poland & 30.1 & 69.9 & 27.2 & 72.8 & 63.8 & 36.2 \\
\hline Ukraine & 64.5 & 35.5 & 63.9 & 36.1 & 82.8 & 17.2 \\
\hline
\end{tabular}

In Austria - 74.2\%, Belgium - 61.4\%, the Netherlands - $66.6 \%$ people believe in supernatural forces, which may be expressed in terms like a Life Force, a Mighty Power, God, a Spirit, a Universal Law, a Cosmic Conscience or a Source of all creation (EVS3, 2001, p. 94). This can be explained, in particular, by the high level of pluralism and relativism in modern societies, which create conditions for the formation and spread of new forms of spirituality, new religious, or rather quasi-religious structures, characterized by diversity and tendency to constant changes ${ }^{10}$. In particular, attempts to find answers, for example, about death outside the traditional religious concepts typical of young Europeans. "It was in thinking about death that English young people were most eclectic in their beliefs drawing on concepts of ghosts, karma and reincarnation as well as heaven" (Collins-Mayo, 2012, p. 90).

\footnotetext{
${ }^{9}$ We combined three tables from the data of EVS3, 2001, pp. 82-84.

${ }^{10}$ For example, occult-esoteric trends "New Age", Christian movements "Neocatechumenate", "Opus Dei", "Comunione e Liberazione" and the others.
} 
One of the tendencies of Western European religious life is the desire of religious denominations to recognize their particularism and obtain a cultural definition in public. Nowadays, the media and religion perform approximately the same functions in maintaining social ties by creating a symbolic space, the spread of standardized messages and maintaining the image of the "faithful". The media also become a space where the image of the "other" is constructed, and here we may observe the dynamics of ostracism, widespread throughout Europe. The results of numerous studies illustrate the following: "in some countries the media sphere is the center (in Denmark) or repeater (in France, Germany) of the transformation of Islam into a threat to a national identity or social unity" (Foret \& Itçaina, 2008). The "caricature" crisis in France showed that the boundaries and forms of the secret in religious traditions continue to be the subject of controversy.

In general, "when we look at the events of a religious life that lie on the surface, we very, very often deal with politics" (Yelenskyi, 2011). The current religious situation in Western Europe to some extent reflects the confrontation between the ideologues of the civilization integration project and the transnational paradigms of Europe and the supporters of the Christian heritage, which must be protected from the prospect of an active European political space. In the European Union there are still people who realize that the erosion of Europe's traditional religious foundations will lead to its future extinction.

Reflecting on the past and present of Europe, Professor Yaroslav Hrytsak (2018) emphasizes that it is in a state of crisis and, unfortunately, in terms of preserving the religious vector, religious instinct, Europe is not an example for Ukraine. But, according to the Ukrainian historian, Europe has little choice but to return to serious conversations about values. Because basically (this is what the historian tells you) there is no other meaning of Europe than the continent of Christianity. And the fact that Europe does not want to admit this is its problem. Because there has to be something called the metaphysics of politics, the metaphysics of identity that makes us bigger than who we are. Europe is blind nowadays, because, relatively speaking, it is being eaten by consumerism and, etc. (Hrytsak, 2018).

The Conclusions and Prospects for Further Research. Western societies remain a relatively secular part of the global world with a civilizational political project and differ in the level of religious diversity and the dynamics of religious change among their populations.

From the point of view of confessional identification, the countries of Western Europe can be attributed to one Christian culture (lost significantly). The majority of Western Europeans believe that churches and other religious organizations play a positive role in society.

According to the criterion of religiosity level, "high religion" is characteristic of countries with the largest number of Orthodox and Catholics (in the global dimension these are Muslim countries).

Non-practicing Christians (people who identify as Christians but who do not attend church) make up the largest proportion of the population. In general, in Western Europe there is a situation when religion is often engaged with "vicariously".

The tendency of religiosity in Western European countries is the subjectification of faith and practice, which complicates the preservation and transmission of religious traditions. As a result, religiosity is situational.

At the end of the XXth - the beginning of the XXIst centuries, according to many researchers, the world experiences an institutional and sociocultural return of religion, although, in our opinion, even in the context of the post-secular paradigm, the deep meanings of a religious tradition are lost. And even nowadays the words of the American Orthodox 
priest Hieromonk Seraphim remain relevant (Eugene Dennis Rose), which written by him during the 70 s of the XXth century:

The way of life of modern "Christians" - a life that is self-centered and self-satisfied became so common that it finally separates them from any understanding of the spiritual life; and when such people turn to the "spiritual life", only as a new form of self-satisfaction (Serafim Iromonah (Rouz), 2005).

We are witnesses of vulgarization, the creation of various distorted forms of religiosity, which generate the unbridled force of destruction. In our opinion, one of the main causes of the spiritual crisis is the gap and disproportion between the deep spiritual content of culture and its representative forms (Tkachenko, 2020, p. 116). Our point of view is the following: the decline of traditional religiosity, which is not a localized tendency and coincidence, continues in Western Europe.

In the future, we would like to focus on international researches - important for assessing broad religious tendencies. Another area of research is migration processes in Europe, which are directly related to the problems of religion and identity. It is worth noting the spread of the so-called "civic religiosity" and the growth of new religious movements.

Acknowledgement. We express sincere gratitude to all members of the editorial board for consultations provided during the preparation of the article for printing.

Funding. The authors did not receive any financial support for the research, authorship, and/or publication of this article.

\section{BIBLIOGRAPHY}

Being Christian in Western Europe. (2018). Being Christian in Western Europe. URL: https://www.pewforum.org/2018/05/29/being-christian-in-western-europe/ [in English]

Bréchon, P. (2008). La religiosité des européens : diversité et tendances communes [Religiosity of Europeans: Diversity and Common Tendencies]. URL: https://www.cairn.info/revue-politiqueeuropeenne-2008-1-page-21.htm [in French]

Breskaja, O. Ju. (2011). Izuchenie religioznosti: k neobhodimosti integral'nogo podhoda [Studying Religiosity: on the Need for an Integral Approach] Sociologicheskie issledovanija - Sociological research, 12 (332), 77-87 [in Russian]

Bruce, S. (2011). Secularization: In Defence of an Unfashionable Theory. Oxford: Oxford University Press, 243 p. [in English]

Collins-Mayo, S. (2012). Youth and Religion: An international perspective. Theo-Web.Zeitschrift für Religionspädagogik - Theo-Web. Journal for Religious Education, 11(1), 80-94. [in English]

Coutinho, José Pereira (2016). Religiosity in Europe: an index, factors, and clusters of religiosity Sociologia, Problemas e Práticas, 81, 163-188 doi: https://doi.org/10.7458/SPP2016816251 [in English]

Davie, G. (2004). New Approaches in the Sociology of Religion: A Western Perspective. Social Compass, 51(1), 73-84. doi: https://doi.org/10.1177/0037768604040791 [in English]

Davie, G. (2006). Religion in Europe in the 21st Century: The Factors to Take into Account. European Journal of Sociology, 47(2), 271-296. doi: https://doi.org/10.1017/S0003975606000099 [in English]

Eisenstadt, S. N. (2000). The Resurgence of Religious Movements in Processes of Globalisation: Beyond End of History or Clash of Civilisations. URL: https://unesdoc.unesco.org/ark:/48223/ pf0000138885.page $=6$ [in English]

Foret, F. \& Itçaina, X. (2008). Dieu loin de Bruxelles.L'européanisation informelle du religieux [God far from Brussels. The Informal Europeanization of Religion] URL: https://www.cairn.info/ revue-politique-europeenne-2008-1-page-5.htm [in French]

Fylypovych, L. (2015). Relihiinist ukraintsiv zdebilshoho sytuatyvna [The Religiosity of the Ukrainians is mostly Situational]. URL: https://tyzhden.ua/Society/139338 [in Ukrainian] 
Habermas, Ju. (2008). Postsekuljarnoe obshhestvo - chto jeto? [Postsecular Society - what is it?]. Rossiǔskaja filosofskaja gazeta-Russian philosophical newspaper, 4 (18), 1-2. [in Russian]

Hrytsak, Ya. (2018). Yevropa - tse kryza [Europe is Crisis]. URL: https://zbruc.eu/node/83180 [in Ukrainian]

Ilyin, I. (2014). Chto takoe religioznost [What is Religiosity]. URL: https://www.mgarsky-monastery.org/kolokol/2180 [in Russian]

Kargina, I. G. (2012). Novye religioznosti: sotciologicheskie refleksii [New Religiosities: sociological reflections]. Vestnik MGIMO-Universiteta - Vestnik MGIMO-Universiteta, 2(23),

186-193. [in Russian]

Pickel, G. (2009). Secularization as a European Fate? Results from the Church and Religion in an Enlarged Europe Project 2006. Church and Religion in Contemporary Europe (Gert Pickel \& Olaf Müller, Ed.). Wiesbaden: VS Verlag für Sozialwissenschaften, 205. [in English]

Serafim Iromonah (Rouz) (2005). Pravoslavie i religija budushhego [Orthodoxy and the Religion of the Future]. URL: https://azbyka.ru/otechnik/Serafim_Rouz/pravoslavie-i-religija-budushhego/ [in Russian]

The European values study: a third wave. (2001). Source book of the 1999/2000 European Values Study Surveys. Tilburg University. URL: https://www.gesis.org/en/services/finding-and-accessingdata/european-values-study/3rd-wave-1999 [in English]

Tkachenko, O. (2020). Relihiina tradytsiia v konteksti postsekuliarnoi paradyhmy [Religious tradition in the context of the postsecular paradigm]. Liudynoznavchi studii: zbirnyk naukovykh prats Drohobytskoho derzhavnoho pedahohichnoho universytetu imeni Ivana Franka. Seriia "Filosofiia" Human Studies. Series of "Philosophy": a collection of scientific articles of Drohobych Ivan Franko State Pedagogical University, 40, 107-120. doi: https://doi.org/10.24919/2522-4700.40.200826 [in Ukrainian]

Tovbin, K. M. (2013). Religioznaja gal'vanizacija kak imitacija tradicionnoj duhovnosti [Religious Galvanization as an Imitation of Traditional Spirituality]. In A. C. Konvers'kij (Ed.). Visnik Kiïvs'kogo nacional'nogo universitetu im. T. Shevchenka. Filosofija. Politologija. - Bulletin of the Kyiv National University. T. Shevchenko. Philosophy. Politology, 3(113), 86-89. [in Russian]

Voas, D. (2005). Religion in Britain: Neither Believing nor Belonging [Religion in Britain: Neither Believing nor Belonging]. Sociology of Religion, 39(1), 11-28. doi: https://doi.org/10.1177/0038038505048998 [in English]

Volodihin, D. M. (2020). Hristianskij personalizm i metod personal'noj istorii v istoricheskoj nauke [Christian Personalism and the Method of Personal History in Historical Science]. URL: https://radonezh. ru/2020/07/03/hristianskiy-personalizm-i-personalnoe-izmerenie-v-istoricheskoy-nauke [in Russian]

Yelenskyi, V. (2009). Hlobalni tendentsii relihiinoho rozvytku u XXI stolitti [Global Tendencies in Religious Development in the XXIst century]. URL: https://risu.org.ua/ua/index/studios/studies_of_ religions/32037 [in Ukrainian]

Yelenskyi, V. (2011). Relihiia "nulovykh": pidsumky desiatylittia [Religion of the "Zeros": the results of the decade]. URL: https://risu.ua/ru/religiya-nulevyh-itogi-desyatiletiya_n45338 [in Ukrainian]

The article was received December 14, 2020. Article recommended for publishing 31/08/2021. 